\title{
The Use of Picture in Teaching Degrees of Comparison
}

\author{
Lukman, Ilham, Hariyati \\ ab University of Muhammadiyah Mataram,Indonesia, ${ }^{a}$ lukman@ummat.ac.id
}

Article history:

Received

Revised

Accepted
The objective of this quantitative study is to investigated whether there any influence of using picture in teaching degree of comparisonor not and to know the students' responses at the second year students of SMP Negeri 9 Mataram in academic year 2014/2015. The population of this study was taken from all the second year students. The writer chose two classses to compare by using technique of taken sample "cluster random sampling". The first class as the experimantal class (A class) was taught by the degree of comparisontrough pictures. The second class as contol class ( B class) was taught without pictures. While 34 students of experimental group and 34 students of control group. This study used experimental study with quantitative method. The data collected procedure by test and questionnaire. The writer gave the pre test, the treatment, the post test and the questionnaire. After collecting and calculating the data, the writer found out that the experimental class gain high score than controll class. Based on the result, the means scores of A class was 25 while B class was 16 . Moreover it was found that the value of $\mathrm{t}$ test was higher than $\mathrm{t}$ table, where $\mathrm{t}$ test $2,5 \leq \mathrm{t}$ table $=2,0(0$, $5 \%$ or $95 \%$ ). The finding showed that there any influnce of using picture in teaching comparison degrees. The picture increase students' responses to learn degree of comparisonin the class and also given good influence concerning students' skill in mastering the subject of comparison degrees. It showed by students' responses of the data from questionnaire that more than a half of students answer yes with percentage was $73 \%$. It means that picture have a great contribution for students in learning comparison degrees. Therefore, it can be concluded that $\mathrm{Ha}$ is accepted and $\mathrm{H} 0$ is rejected.

\section{Introduction}

Teaching degree of comparisonby using pictures that will make the students can focus on their activities and they will be interested in learning. It can be used to create situation for English classroom more fun and that keeps the students from getting bored. By showing pictures in teaching degrees of comparison that can help the students to understand the material and compare the forms of degree of comparisoneasily. So, the students would not confuse and difficult to understand the material. Teaching showing picture can make the student remember more, more impressive, more interesting and more focused. (Ruis, 2003: 87).

From explanation above, it shows that picture is a suitable media that can be used in teaching English language. It means that picture also can be used for teaching comparison degrees. It is expected that this method can give better result and can increase students comprehend to master degree of comparisonvery well. Pictures are one of the valuable aids which bring "images of reality into the unnatural world of the language classroom" (Hill: 1990). They are also useful to attract learners' attention to the materials being taught.

In our live every day, we always making comparison between person with other person or one thing with another. In English, it is call degrees of comparison (Zainal Hitam, 2005: 126 - 127). Degrees of comparison are used when we compare one person or one thing with another. According to Thurman (2002: 29) that in writing comparisons, you can use one of three different forms (called degrees) of adjective and adverb: Positive degree is simply makes a statement about a person, place, or thing. Comparative degree is compares two (but only two) people, places, or things. Superlative degree is compares more than two people, places, or things.

Degree of comparisonis one of the components of grammar in teaching English language. Grammar is a part of language and an important element in English. According to Harmer (2007: 12) that grammar of a language is the description of the ways in which words can change their forms and can be combined into sentences in the language. From this definition, it seems that grammar plays an important in learning foreign language. It is the main capital in studying english. Without a good knowledge in grammar, the learners will 
find many problems in make sentences for communication. By using the proper grammar, the student will know how words can or cannot be combined in sentences for communication to express their ideas and feelings.

In reality, most Indonesian students face difficulties in learning grammar because the grammatical rules of Indonesian language are different from those of English. It is obvious why they become passive, confused, not focus, afraid of making mistakes, and feel bored when they study English grammar. It is one of the problems faced by students of SMP Negeri 9 Mataram. It can lead the learners have negative result, they become lazy to learn it and unable to communicate in English. So, to solve of the problem above, the writer try to using media picture as method in teaching comparison degrees.

According to Tang Li Shing (1981:11) "The Picture had an irascible appeal for the children. They created suspense and surprises as well as interest, all of which are indispensable in teaching and learning a foreign language". The use pictures is one of the best teaching aids in learning English. They not only make class become more active and alive, but also help student learn English easily.

There are several previous studies on the use of picture media in teaching degrees of comparison. First, Siti Munajah (2011), the writer concludes that pictures help the students to understand the difficult of reinforcing degrees of comparison of adjective by looking at the picture, the use of the pictures makes the reinforcing degrees of comparison of adjective become enjoyable and interesting. Second, Susilawati (2009), the writer suggest to the teachers to use visual media when they teach especially degrees of comparison because it is more effective. English teacher needs to have well preparation in their classroom in choosing media properly when she/he teaches degrees of comparison in order to make students comprehend easily and not to make the students feel bored.

Overall, from the previous studies which have been mentioned only a few studied discussed the use of picture in teaching comparison degrees. Therefore, the study of picture in teaching degrees of comparison will provide additional dimension in grammar research. In addition, regarding to the fact above, there is need conduct a study of using picture in teaching comparison degrees.

Based on the statements above, the writer intended to study more and choose the topic about "the use of picture in teaching comparison degrees" at the second year students of SMP Negeri 9 Mataram in academic 2014/2015. So the purposes of study are to investigate the influence of using picture in teaching degree of comparisonat the second year students of SMP Negeri 9 Mataram in academic year 2014/2015. And to know the students' responses in learning degree of comparisonby using picture at the second year students of SMP Negeri 9 Mataram in academic year 2014/2015.

\section{Review of Literature}

\section{A. Teaching Degree of comparison Using Picture}

Teaching is a process of transferring knowledge. It is successfully if the objective taught is acceptable well by the learners taught at the level. Teaching degree of comparisonmeans that how the objective of transferring degree of comparisonknowledge is obtained and understandable. Indonesian new English teacher often find difficulty to bring the lesson to his or her students. Because the way of teaching degree of comparisonruns ineffectively or ambiguity. Therefore, their English teaching program is failure.

There are several methods in teaching learning grammar of comparisons degrees. One of them by using picture. Pictures are one kind of media that can help the teacher draw the students ${ }^{\text {ee }}$ interest and built their motivation. It is very simple visual aids that can be picked up from the photograph, flashcard, book, etc.. If the students are motivated, they will participate actively and will learn hard during the teaching learning process. According to Wright (1989: 2) pictures contribute to interest and motivation, a sense of context of the language, and a specific reference point or stimulus.

Based on the explanation above, it can be concluded that pictures as media in teaching process is suitable with teaching grammar of comparison degrees. Pictures have an important role and advantages in teaching learning process in order to make the students still focus and understand the material easily. That is also can make the students interest to learn the material. According to Wright (1994: 128) "the most benefit of a picture can makes is to contribute to the student's understand of a more general context which may be made up of pictures, the teacher's actions, the student's actions, sound effects and words. This overall context of new language will have meaning to the students". With the exercise that is designed to develop particular skills in grammar, especially degrees of comparison. Picture can be used to provide either the general context or to illustrate particular points. In addition, picture can be used by the students to help their understanding none verbally. 


\section{III.Research Method}

In this study, the writer used quantitative method and choose experimental research to solve classroom problems through the application of the scientific method. Meanwhile, to identify the use of picture in teaching degree of comparison the second year students of SMP Negeri 9 Mataram in academic year of 2014/2015 the writer using true-experimental design (pretest-posttest control group design)

The writer chose the true-experimental design because the researcher could controlling all of external variable that influenced internal variable. So that, validity internal could be high. In this reserch design, there were two groups that were chosen randomly, and then they were given pretest to know the initial condition whether there was a difference between experiment group and control group. The formula of this design could be seen as follow (Sugiyono, 2013: 223).

Table 0.4 Formula of Pretest-Posttest Control Group Design

\begin{tabular}{|llll|}
\hline $\mathrm{R}$ & $\mathrm{O}_{1}$ & $\mathrm{X}$ & $\mathrm{O}_{2}$ \\
$\mathrm{R}$ & $\mathrm{O}_{3}$ & & $\mathrm{O}_{4}$ \\
\hline
\end{tabular}

Where:

$\mathrm{R}$ : Experimental and control class that are chosen randomly

$\mathrm{O} 1 \& \mathrm{O} 3 \quad$ : Pre-test of experimental and control class

$\mathrm{O} 2$ \& $\mathrm{O} 4 \quad$ : Post-test of experimental and control class

$\mathrm{X}$ : Treatment

\section{A. Population and Sample}

This section discusses about population, sample and the way how to took the sample.

\section{Population}

Population is all the subject of the research, Arikunto (2010: 173). The while, according to Hill (2012: 91) that the larger group to which one hopes to apply the results is called population. In this study, the population was the second year students of SMP Negeri 9 Mataram in academic year 2015/2015 which consisted of 8 classes:

Table 0.5 Population of the Research

\begin{tabular}{ccc}
\hline No. & Class & Number of Student \\
\hline 1. & VIII A & 36 \\
\hline 2. & VIII B & 36 \\
\hline 3. & VIII C & 36 \\
\hline 4. & VIII D & 36 \\
\hline 5. & VIII E & 36 \\
\hline 6. & VIII F & 36 \\
\hline 7. & VIII G & 36 \\
\hline 8. & VIII H & 36 \\
\hline & $\sum$ & 288 Students \\
\hline
\end{tabular}

\section{Sample}

A sample is any part of a population of individuals on whom information is obtained. It may, for a variety of reasons, be different from the sample originally selected, Hill (2012: 106). The while, for experimental reserch who simple, that using experimental group and control group, so that the number of sample member is respective between 10-20, Sugiyono (2014: 132)

In this study, the writer used cluster random sampling technique to take the sample because has larger numbers of clusters. According to Hill (2012: 106) that a cluster random sample is one obtained by using groups as the sampling unit rather than indivuduals. To facilitate in choose the random sample, the writer using lottery. The writer wrote down number 1 to 8 as many as total of class on small piece of paper. The small piece of paper is roll and mixed. Then, without prejudice 
the writer take two small piece of paper, they were; the first taken was class VIII A as the experimental class and the second taken VIII B as the control class, Arikunto (2010: 180).

\section{B. Data Collection Technique}

The instrument of the study was a tool or facility that was used in collecting data in order to get better result. To get the accurate data, in this study the writer chose some instruments for collecting the data, they were:

\section{a. Test}

To measure there was or not as well as the magnitude of the object under study ability, used the test. According to Arikunto (2010: 193), the test is a series of questions or exercises and other tools used to measure skill, knowledge, intelligence, ability or talent possessed by individuals or group. In this study, the writer conducted a pre-test, treatment and post-test.

\section{- Pre-test}

Pre-test was given before the teacher teaches new material by using pictures, the teacher asked students to do the test related in the materials that they had known about grammar of degree of comparisonby them before. This test was given before the experiment run.

\section{- Treatment}

The writer gave a set of treatmens by using picture for the experimental group. Meanwhile, the control group did not gave treatments by using picture but other method such as completed sentences, multiple choices, etc. the topic and lesson plan of teaching learning activities during treatments process was the same for the experimental and control groups.

\section{- Post test}

Post-Test was conducted after treatment given. It was aimed to measure the students' achievement after applying two media to compare the result between pre-test and post-test that was processed into data. Materials of the test was taken from the grammar degree of comparisonwhich was taught in the activities before.

\section{b. Questionnaire}

Questionnaire is technique of the collecting data that doing of the way given a set question or written statement to respondent for they answer to know what could be expected from the respondents. Questionnaires can be closed-ended questions or open; can be given to the respondent directly or sent by mail, or the Internet. (Sugiyono, 2013: 199).

The collecting data did by using device measure namely a sheet questionnaire of Guttman scale, the data gained that were interval data or two alternative (rasio dikotomi) was "yes" and "no". Guttman scale is also call as scalogram scale that very good to convience the writer about the dimension unit and attitude or characteristic that researched, It is always call atribut universal" (ridwan, 2008: 42).

Table 0.7 Scoring of Guttman Scale

\begin{tabular}{ccc}
\hline Answer alternative & \multicolumn{2}{c}{ Score of answer alternative } \\
\cline { 2 - 3 } & Positif & Negative \\
\hline Yes & 1 & 0 \\
\hline No & 0 & 1 \\
\hline
\end{tabular}

Then, percentage the data was gained to translatable in category as follow:

Table 0.8 Category of Persentase

\begin{tabular}{cc}
\hline Percentage & Category \\
\hline $0-1 \%$ & Nothing \\
\hline $2 \%-25 \%$ & A little \\
\hline $26 \%-49 \%$ & Less than a half of \\
\hline $50 \%$ & A half \\
\hline $51 \%-75 \%$ & More than a half \\
\hline $76 \%-99 \%$ & Most of \\
\hline $100 \%$ & All of \\
\hline
\end{tabular}




\section{Data Analysis Technique}

In this case, the writer used t-test to analyze data from test and used guttman scale to analyze data from questionnaire.

\section{Analysis from Test}

In analyzing the data, the writer used t-test to determine whether or not there was an influenced using picture in teaching comparison degrees. The steps under taken in quantitative analysis was described as follow:

First, find out mean scores of the two groups. The writer applied the following formula:

Find out the mean scores of experimental group.

$$
\mathrm{Mx}=\frac{\sum \mathrm{X}}{\mathrm{N}}
$$

Find out the mean score of control group.

$$
\mathrm{My}=\frac{\sum \mathrm{Y}}{\mathrm{N}}
$$

Explanation:

$M$ : The mean score of the two groups

$\mathrm{X}$ : The students' final scores for experimental group

Y : The students' final scores for control group

$\mathrm{N}$ : The number of sample

$\sum$ : The sum of

After finding mean of the students, the writer calculated the deviation of the student. To calculated deviation scores, the writer used score formula:

Find out the standard deviation of experimental group. The formula was:

$$
\sum \mathrm{x}^{2}=\sum \mathrm{X}^{2}-\frac{\left(\sum \mathrm{X}\right)^{2}}{\mathrm{~N}}
$$

Find out the standard deviation of control group. The formula was:

$$
\sum \mathrm{y}^{2}=\sum \mathrm{Y}^{2}-\frac{\left(\sum \mathrm{Y}\right)^{2}}{\mathrm{~N}}
$$

Explanation:

$\sum \mathrm{y}^{2}:$ The standard deviation for control group

$\sum \mathrm{x}^{2}:$ The standard deviation for experimental group

$\mathrm{X}^{2}$ : The Square of the deviation score in experimental group.

$\mathrm{Y}^{2}$ : The Square of the deviation score in control group.

$\mathrm{N}$ : The number of sample

$\sum$ : The sum of 
Find out the significance different between the pre-test and post-test by calculating ttest, the following formula:

$$
t=\frac{M x-M y}{\sqrt{\frac{\sum x^{2}+\sum y^{2}}{(N x+N y)-2}\left[\frac{1}{N x}+\frac{1}{N y}\right]}}
$$

Explanation:

Mx : Mean score of control group

My : Mean score of experimental group

$\mathrm{x}^{2} \quad$ : The deviation of control group

$y^{2} \quad$ : The deviation of experimental group

$\mathrm{Nx}$ : The sample of the experimental group

Ny : The sample of the control group

$\Sigma$ : The sum of...

$\sqrt{ }:$ The root of ...

If $\mathrm{t}$-test $\leq \mathrm{t}$-table in the significance of $0,05(\mathrm{p}=0,01)$, Null hypothesis (Ho): "The use of picture does not motivate students in learning comparison degrees" is rejected. It means that the experimental group have higher score than control groups.

If $t$-test $\geq \mathrm{t}$-table in the significance level of $0,05(\mathrm{p}=0,01)$, Alternative hypothesis $(\mathrm{Ha})$ : "The use of picture motivates students in learning comparison degrees" is accepted. It means that the control group have lower score than experimental group.

(Arikunto, 2010: 350-354)

\section{Analysis from Questionnaire}

In analyzing the data, find out the students' responses. After gaining data of questionnaire the writer processed the data by using percentage to know the result of students answer and response. The formula of percentage students' responses as follow :

$$
\begin{aligned}
& \mathrm{P}=\frac{\mathrm{f}}{\mathrm{n}} \times 100 \% \\
& \text { Explanation: } \\
& \mathrm{P} \quad=\text { Percentage } \\
& \mathrm{f} \quad=\text { Frequency of each the answer was choose } \\
& \mathrm{n} \quad=\text { Sum of sample } \\
& 100 \% \quad=\text { Constant }
\end{aligned}
$$

( Bungin, 2010: 177)

\section{Results and Discussion}

This analysis leads the finding to the discussion of this study, and then the finding is continued to the analysis of discussion before arriving at the calculation. In finding and discussion, the writer presented the mean score of pre-test and post-test of each group between experimental and control groups. In analyzing the data, the writer carried out some ways, there were: firstly, the writer divides the students' individual score of pre-test and post-test by these groups. Secondly, analyzes the mean score of both groups by divide the deviation score. And the third, calculates the result of students' responses. 


\section{A. Findings}

Findings presented the result by test and questionnaire. The result from test is finding the data of pre pre-test and post-test and analyzing deviation score of two groups to know the result of t-test. Then, analyze students' responses by using picture in teaching comparison degrees.

\section{Data from Test}

In this section the writer analyzed the result of student's score in pre-test and post-test. The analyses done by computing of mean score, standard deviation, and analyzing of t-test value both experimental and control groups.

Table 0.9

Computation of the Students' Deviation Score of Experimental Group (X)

\begin{tabular}{|c|c|c|c|c|c|}
\hline No. & Students & Pre-Test (Xa) & Post-Test (Xb) & $\mathrm{X}$ & $\mathrm{X} 2$ \\
\hline 1. & AH. A & 38 & 88 & 50 & 2500 \\
\hline 2. & AH. I.W & 40 & 88 & 48 & 2304 \\
\hline 3. & AL. A & 28 & 64 & 36 & 1296 \\
\hline 4. & AN. A.N & 39 & 73 & 34 & 1156 \\
\hline 5. & AR. R.P & 24 & 49 & 25 & 625 \\
\hline 6. & AR. H & 70 & 89 & 19 & 361 \\
\hline 7. & AZ. H & 35 & 63 & 28 & 784 \\
\hline 8. & BAIQ. F.E & 34 & 46 & 12 & 144 \\
\hline 9. & BAIQ. I.W & 27 & 32 & 5 & 25 \\
\hline 10. & DE. R & 42 & 37 & -5 & 25 \\
\hline 11. & EM. Y & 33 & 42 & 9 & 81 \\
\hline 12. & ER. A.N & 30 & 79 & 49 & 2401 \\
\hline 13. & HA & 39 & 51 & 12 & 144 \\
\hline 14. & HA. A.F & 29 & 69 & 40 & 1600 \\
\hline 15. & HE. S & 31 & 85 & 54 & 2916 \\
\hline 16. & IB. $\mathrm{H}$ & 44 & 29 & -15 & 225 \\
\hline 17. & ID & 18 & 31 & 13 & 169 \\
\hline 18. & JO. Z & 47 & 38 & -9 & 81 \\
\hline 19. & MA. R.Y & 24 & 32 & 8 & 64 \\
\hline 20. & MU. R & 34 & 88 & 54 & 2916 \\
\hline 21. & MU. I.R & 15 & 79 & 64 & 4096 \\
\hline 22. & MU. N & 35 & 88 & 53 & 2809 \\
\hline 23. & PA. P.A & 34 & 64 & 30 & 900 \\
\hline 24. & RI. A.G & 35 & 69 & 34 & 1156 \\
\hline 25. & SE. H & 30 & 84 & 54 & 2916 \\
\hline 26. & SU. D.H & 39 & 63 & 24 & 576 \\
\hline 27. & SU. H & 24 & 69 & 45 & 2025 \\
\hline 28. & TA. E.T & 44 & 48 & 4 & 16 \\
\hline 29. & TA. H & 29 & 68 & 39 & 1521 \\
\hline 30. & WA. N & 26 & 31 & 5 & 25 \\
\hline 31. & WI. K.S & 59 & 90 & 31 & 961 \\
\hline 32. & ZULH & 48 & 60 & 12 & 144 \\
\hline 33. & ZULK & 62 & 73 & 11 & 121 \\
\hline 34. & ZU. H & 38 & 31 & -7 & 49 \\
\hline \multicolumn{2}{|r|}{$\sum$} & 1224 & 2090 & 866 & 37132 \\
\hline
\end{tabular}

Explaination:

$\mathrm{Xa}$ : The score individual of pre-test.

$\mathrm{Xb}$ : The score individual of post-test.

$\mathrm{X}$ : The deviation score of pre-test and post-test in experimental group.

$\mathrm{X} 2$ : The Square of the deviation score in experimental group. 
Table 0.10 Computation of the Students' Deviation Score of Control Group (Y)

\begin{tabular}{|c|c|c|c|c|c|}
\hline No. & Students & Pre-Test (Ya) & Post-Test (Yb) & $\mathrm{Y}$ & Y2 \\
\hline 1. & AL. I & 24 & 57 & 33 & 1089 \\
\hline 2. & AN. K & 28 & 47 & 19 & 361 \\
\hline 3. & AR. W & 23 & 32 & 9 & 81 \\
\hline 4. & AR. K & 36 & 28 & -8 & 64 \\
\hline 5. & AR. H & 18 & 28 & 10 & 100 \\
\hline 6. & AYL & 33 & 48 & 15 & 225 \\
\hline 7. & AY & 20 & 54 & 34 & 1156 \\
\hline 8. & DE. A.S & 37 & 48 & 11 & 121 \\
\hline 9. & DE. F.H & 26 & 48 & 22 & 484 \\
\hline 10. & EK. R.N & 29 & 38 & 9 & 81 \\
\hline 11. & FI. Y.S.D & 23 & 43 & 20 & 400 \\
\hline 12. & GE. A.A.P.B & 36 & 28 & -8 & 64 \\
\hline 13. & GU. A.M.M.J & 32 & 57 & 25 & 625 \\
\hline 14. & I KE. B.J & 28 & 42 & 14 & 196 \\
\hline 15. & I MA. B.L.Y & 23 & 42 & 19 & 361 \\
\hline 16. & I MA. P & 23 & 42 & 19 & 361 \\
\hline 17. & ID. A.G.A & 34 & 57 & 23 & 529 \\
\hline 18. & JA. Z & 28 & 57 & 29 & 841 \\
\hline 19. & MA. R & 48 & 38 & -10 & 100 \\
\hline 20. & MI.R & 29 & 47 & 18 & 324 \\
\hline 21. & MU. D.R. N & 23 & 53 & 30 & 900 \\
\hline 22. & NI. L.E.A & 34 & 49 & 15 & 225 \\
\hline 23. & NI. N.D.S.D & 29 & 54 & 25 & 625 \\
\hline 24. & NI. P.A.O & 23 & 62 & 39 & 1521 \\
\hline 25. & NI. P.D. & 39 & 57 & 18 & 324 \\
\hline 26. & NI. L & 16 & 26 & 10 & 100 \\
\hline 27. & NU. M & 29 & 62 & 33 & 1089 \\
\hline 28. & RI. S.E.S & 36 & 33 & -3 & 9 \\
\hline 29. & RI. A & 29 & 46 & 17 & 289 \\
\hline 30. & SA. R & 42 & 47 & 5 & 25 \\
\hline 31. & SA. M & 28 & 52 & 24 & 576 \\
\hline 32. & SE. J.A & 42 & 38 & -4 & 16 \\
\hline 33. & YA. S & 36 & 48 & 12 & 144 \\
\hline \multirow[t]{2}{*}{34.} & ZA. H & 20 & 72 & 52 & 2704 \\
\hline & & 1004 & 1580 & 576 & 16110 \\
\hline
\end{tabular}

Explaination :

Ya : The score individual of pre-test.

$\mathrm{Yb}$ : The score individual of post-test.

Y : The deviation score of pre-test and post-test in control group.

Y2 : The Square of the deviation score in control group.

Based on data test above, the writer started from the calculation of students the mean score, deviation score, and identification of significance t-test of experimental and control groups.

The computation means score of experimental and control groups.

After getting the score deviation of pre-test and post test, the mean score is obtained by dividing the sum of deviation score with the number of sample in the group. To gain the mean score of the investigation, the writer used the formula below:

The mean score of Experimental group

In the table 0.9 , it was knew that:

$\sum \mathrm{X}=866$

$\mathrm{N}=34$

So, the mean score of experimental group was: 


$$
\begin{aligned}
& M x=\frac{\sum X}{N} \\
& =\frac{866}{34} \\
& =25,47 \\
& =25
\end{aligned}
$$

The mean score of Control group

In the table 0.10 , it was knew that:

$\sum \mathrm{Y}=576$

$\mathrm{N}=34$

So, the mean score of control group was:

$$
\begin{aligned}
& \text { My }=\frac{\sum Y}{N} \\
& =\frac{576}{34} \\
& =16,94 \\
& =16
\end{aligned}
$$

The computation of the standard deviation of experimental and control groups.

This section discussed the calculation of standard deviation of mean score the groups. The computation can be calculated by using the formula below:

The standard deviation of experimental group

In the table 0.9, it was knew that:

$\sum \mathrm{X}^{2}=37132$

$\mathrm{N}=34$

So, the standard deviation of experimental group was:

$$
\begin{aligned}
& \sum x^{2}=\sum X^{2}-\frac{\left(\sum X\right)^{2}}{N} \\
& =37132-\frac{(866)^{2}}{34} \\
& =37132-\frac{749956}{34} \\
& =37132-22057,52 \\
& =15074,48 \\
& =15074
\end{aligned}
$$

The standard deviation of control group

In the table 0.10 , it was knew that:

$\sum \mathrm{Y}^{2}=16110$

$\mathrm{N}=34$

So, the standard deviation of control group was: 


$$
\begin{aligned}
& \sum \mathrm{y}^{2}=\sum \mathrm{Y}^{2}-\frac{(}{(576)^{2}} \\
& =16110-\frac{34}{34} \\
& =16110-\frac{33176}{34} \\
& =16110-9758,11 \\
& =6351,89 \\
& =6352
\end{aligned}
$$

The Computation and analysis of t-test

To know the significance value the writer has formulated t-test to get the result between experimental and control groups. Arikunto (1991: 252) suggested the formula of t-test to compare the deviation of two mean scores and to measure whether the deviation is significance or not, the formula as follow:

$$
\begin{aligned}
\mathrm{t} & =\frac{M x-M y}{\sqrt{\frac{\sum \mathrm{x}^{2}+\sum \mathrm{y}^{2}}{(\mathrm{Nx}+\mathrm{Ny}-2}\left[\frac{1}{\mathrm{Nx}}+\frac{1}{\mathrm{Ny}}\right]}} \\
& =\frac{25-16}{\sqrt{\frac{15074+6352}{(34+34)-2}\left[\frac{1}{34}+\frac{1}{34}\right]}} \\
& =\frac{9}{\sqrt{\frac{21426}{(68)-2}[0,02+0,02]}} \\
& =\frac{9}{\sqrt{\frac{21426}{66}[0,04]}} \\
& =\frac{9}{\sqrt{324,63[0,04]}} \\
& =\frac{9}{\sqrt{12,98}} \\
& =\frac{9}{3,60}
\end{aligned}
$$

Table 0.12 Result of Questionnaire

\begin{tabular}{ccc}
\hline Item Number & "Yes" Answer & "No" Answer \\
\hline 1. & 34 & 0 \\
\hline 2. & 14 & 20 \\
\hline 3. & 33 & 1 \\
\hline 4. & 0 & 34 \\
\hline 5. & 29 & 5 \\
\hline 6. & 28 & 6 \\
\hline 7. & 30 & 4 \\
\hline 8. & 32 & 2 \\
\hline 9. & 7 & 27 \\
\hline
\end{tabular}




\begin{tabular}{ccc}
\hline 10. & 25 & 9 \\
\hline 11. & 33 & 1 \\
\hline 12. & 32 & 2 \\
\hline 13. & 33 & 1 \\
\hline 14. & 33 & 1 \\
\hline 15. & 7 & 27 \\
\hline$\sum$ & 370 & 140 \\
\hline Average & 25 & 9 \\
\hline
\end{tabular}

Based on the table above, the writer was percentage the result of questionnaire using formula below:

Calculation of answer "Yes".

$$
\begin{aligned}
P & =\frac{f}{n} \times 100 \% \\
& =\frac{25}{34} \times 100 \% \\
& =73,52 \% \rightarrow \quad 73 \%
\end{aligned}
$$

Calculation of answer "No".

$$
\begin{aligned}
& P=\frac{f}{n} \times 100 \% \\
& =\frac{9}{34} \times 100 \% \\
& =26,47 \% \rightarrow \quad 26 \%
\end{aligned}
$$

\section{B. Discussion}

In this part, the writer presented the discussion of the result from test and questionnaire above to know the effect of using picture and students' response in teaching comparison degrees.

\section{Discussion from Data Test}

This part would discuss the result of the previous finding. After the data has analyzed it has found differences score between experimental group and control group and would discussed the results significantly t-test value obtained from each item.

Based on the collected data, the writer found that the mean score of experimental group is higher than mean score of control group, while the mean score of experimental group is 25 and the mean score of control group is 16 . Commonly in education study the level of significance used are 05 and 01 , while the degree of freedom is $\mathrm{N}-2$ become $68-2=66$. Futhermore, the result of the computation of t- test value of the two groups equal 2, 5. It indicates that the treatment was successful. Also, it can be seen that if we check up the t-table, the writer found out that the t-table for confidence 0,5 or $95 \%$ was 2,00 . If we compared the test to t-table we will find that: T-test $2,5 \leq \mathrm{t}$-table $=2,00$ $(95 \%)$.

It means that the study indicated that the degree of difference in confidence two levels 0,05 was significance at the two confidence levels. The result above showed that the null hypothesis is rejected and alternative hypothesis is clearly accepted. So, the picture has positive influence in teaching comparison degrees.

\section{Discussion from Data Questionnaire}

Based on the result of questionnaire above, the writer calculated the percentages the students' responses based on the category in chapter 3 . The data showed that more than a half of the students answer "yes" with percentages $73 \%$. Meanwhile, the averages percentages of the students answer "no" $26 \%$. It can be concluded that the picture give the significant contribution for students in 
learning comparison degrees. So, the picture is very good and suitable if used as a media to learning comparison degrees.

\section{Conclusion and Suggestion}

\section{A. Conclusion}

Arriving at the last chapter, this study concluded that the optimal application of picture can not significantly help the teacher and their students in teaching learning process especially comparison degrees. Because this media can not increase students' comprehend. In this particular conclusion is taken after having the result of treatments down in pre-test and post-test.

Based on the result from computation of the mean score while the score of experimental group is 25 and the score of control group is 16 , while the level significance used $0,5 \%$ and $0,1 \%$ with the degree of freedom is $\mathrm{N}-2$ become $68-2=66$. It indicates that the treatment was not successful. Furthermore, it was found that the value of $t$ t test was lower than $t$ table, where $t$ test $2,5 \leq t$ table $=2,0(0,5 \%$ or $95 \%)$.

Moreover, data from questionnaire shows that the averages percentages the students answer "yes" $37 \%$. Meanwhile, averages percentages students answer "no" $26 \%$. It can be concluded that less than a half of students' responses by using picture media in learning comparison degrees.

So, by using picture in teaching degree of comparisonhas positive influence for students. The picture increase students' comprehend in learn comparison degrees. The students more comprehend the lesson easily more effective to do various activities in learning comparison degrees. So, the students do not feel bored when the learning.

It is clear there that the null hypothesis (Ho) which sounds "The use of picture does not increase students comprehend in mastering comparison degrees," is clearly rejected. Mean while alternative hypothesis $(\mathrm{Ha})$ which stated "The use of picture increase students comprehend in mastering comparison degrees," is definitely accepted.

\section{B. Suggestion}

Based on the conclusions above, the suggestion of the research goes to the number of people bellow:

For the Teacher

1. The teachers must be creative and make a various technique in teaching English especially in teaching grammar so that the students do not get bored especially in learning process.

2. The teachers are suggested that they keep using picture in teaching especially in teaching comparison degrees. In this case, the teachers are suggested they improve the application of such media by making them more colorful and attractive.

3. The English teacher should develop the ability of the students in speaking by giving the students more chance to practice English language and speak their opinion freely, so that their ability will be improved.

For the Students

1. The students should keep spirit in learning grammar to increase their ability so that they have a better achievement in learning English.

2. The students must practice English speaking every day, everywhere, and study hard to improve their speaking to be a better in future.

For the Next Researchers

1. The other research on this field should raised one important research question regarding to any factors which may contribute the effectiveness of using picture in teaching and learning process.

2. The next researcher should be better in doing research so that giving the important benefit to increase education method be more creative, communicative and be the best especially in indonesian education. 


\section{Reference}

1. Arikunto, S. 2010. Prosedur Penelitian; Suatu Pendekatan Praktik. Jakarta: PT. Rineka Cipta.

2. Aqel, M. I. 2013. The Effect of Using Grammar Translation Method on Acquiring English as A Foreign Language: International Journal of Asian Social Science.

3. Bungin, B. 2010. Metode Penelitian Kuantitatif. Jakarta: Prenada Media Group

4. Crystal, D. 2004. In Word and Deed (Magazine Article): TES Newspaper.

5. Eastwood, J. 2002. Oxford Guide to English Grammar (Seventh Impression), New York: Oxford University Press

6. Harmer, J. 2007. The Practice of English Language Teaching (4th. ed), Cambridge: Longman Publishing.

7. Hays, D. R and Ellikson, L. P. 1990. Guttman Scale Analysis of Longitudinal Data: A Methodology and Drug Use Applications: The International Journal of the Addictions, 25 (11 A), 1341-1352.

8. Hill, G. Mc. 2012. Connect Learn Succeed. New York: McGraw-Hill Companies, Inc.

9. Hornby. 2007. Oxford Advanced Learner's Dictionary, New York: Oxford University Press.

10. Hughes, A. 2003. Testing for Language Teachers. Cambridge: Cambridge University Press.

11. Jaiswal, P. 2005. Techniques for Teaching Adjectives and Four Classroom Activities: The internet TESL Journal, Vol. XI, No 9.

12. Ko admin. 2011. The Advantages and Disadvantages of Picture Used. Blog.

13. Mansourza, M. 2014. A Comparative Study of Teaching Vocabulary through Pictures and Audio-visual Aids to Young Iranian EFL Learners. Journal of Elementary Education Vol.24, No. 1 pp. 47-59.

14. Munajah, S. 2011. The Effectiveness of Using Pictures in Reinforcing Degrees of Comparison of Adjective (An Experimental Study at the Second Grade of Students MTS Al-Falah Bogor). Department of English Education, the Faculty of Tarbiyah and Teachers' Training, States Islamic University Syarif Hidayatullah, Jakarta.

15. Nguyenthihamy92. 2013. Picture as Teaching Aid, Teaching Aid: Journal for PELT.

16. Nguyenxuanspa. 2013. Using Picture in Teaching English, Teaching Aid: Journal for PELT.

17. Pardiyono. 2006. Communicative Grammar for Easy Conversation, Yogyakarta: C .V ANDI OFFSET (Penerbit ANDI).

18. Pu, Wang. 2011. Consideration about ESL/EFL Grammar Instruction. School of Foreign Studies, Henan Polytechnic University of China: M \& D FORUM.

19. Richard, C. J and Renandya, A. W. 2003. Methodology in Language Teaching (An Anthology of Current Practice), New York: Cambridge University Press

20. Ridwan. 2008. Dasar-Dasar Statistika (Cetakan Ke-6), Bandung: Alfabeta Bandung.

21. Ruis, N. 2003. Instructional Media, Jakarta: PPPG Bahasa Jakarta.

22. Syaifullah Education Information Center. 2008. Some Theories About English Teaching Media. Blog.

23. Sugiyono. 2013. Metode Penelitian Pendidikan: Pendekatan Kuantitatif, Kualitatif, dan R\&D, Bandung: ALFABETA, CV.

24. Susilawati. 2009. Teaching Degrees of Comparison Using Visual Media (An Experimental Study at the Second Year of SMP PGRI 1 Ciputat). Department of English Education, the Faculty of Tarbiyah and Teachers' Training, States Islamic University Syarif Hidayatullah, Jakarta.

25. Thornbury, S. 2002. How to Teach Grammar, Malaysia, PP. Bluestone Press, Charlbury, Oxfordshire, UK.

26. Thurman, S. 2003. The only grammar book; you'll ever need, U.S.A: F+W Media, Inc.

27. Zainal, Hitam, R.C 2005. Pelajaran Bahasa Inggris Sistem Tanpa Guru, Surabaya: Indah Surabaya.

28. Yule, G. 2010. The Study of Language: Fourth Edition, Cambridge: Cambridge University 